\title{
FirST ASSESSMENT OF HYBRID SPARROW (PASSER DOMESTICUS X P. HISPANIOLENSIS) DAMAGE ON Cereal Crops in OUARgla (Algeria)
}

\author{
Hafsa Benras', Omar Guezoul ${ }^{2}$, Ahlame Benghedier², Atika Korichi² \\ ${ }^{1}$ Kasdi Merbah Ouargla University, Ouargla, Algeria \\ ${ }^{2}$ Faculty of Natural and Life Science, Saharan Bio-Resources Laboratory: Preservation \\ and Development, Université Kasdi Merbah University, Ouargla 30000, Algeria
}

(Received March 2019 - Accepted August 2019)

\begin{abstract}
Benras, H. Guezoul, O. Benghedier, A. Korichi. A. 2019. First assessment of hybrid sparrow (Passer domesticus $\boldsymbol{x}$ P. hispaniolensis) damage on cereal crops in Ouargla (Algeria). Lebanese Science Journal. 20(3): 380-390.

The current study was carried out in 2016 and 2017 in eight cereal farms in Ouargla, in the north of Algerian Sahara. The damage caused by hybrid sparrows on cereals (barley and wheat) showed that the loss due to individuals of (Passer domesticus $x P$ hispaniolensis) on cereal plots varies between the visited farms and fluctuates between $0.28 \%$ (0.22 qls / ha) and 15.6\% (10.8 qls / ha). In general, the damage caused by the sparrows was found to be more important on the periphery of the plots than in the centers of these plots. A significant relationship was found between the rate of damage and the approach of cereal plots to tree blocks, and the density of ears per sampled square. A good decision on the position of cereal plots within farms seems to be $a$ priority to avoid sparrow attacks.
\end{abstract}

Keywords: cereal crops, hybrid sparrow (Passer domesticus $x$ P. hispaniolensis), damage, Algerian North-Eastern Sahara, Ouargla, Algeria.

\section{INTRODUCTION}

The cultivation of Large-scale cereal plots in the Algerian Sahara started at the end of 1980s (CHAOUCH, 2018). In Ouargla, in the north-eastern of the Algerian Sahara, technical and phytosanitary constraints are the most frequently stated problems with cereal cultivation (DJILI et al., 2003). The introduction of cereals under Centre-pivot irrigation system in the Algerian Sahara has led to the outbreak of certain pests of cultivated crops. Already in (2002), OULD EL HADJ observed solitary forms of the migratory locust (Locusta migratoria) on crops under Centre-pivot irrigation system at 
Tamanrasset, Adrar, El Goléa, Ghardaïa and Ouargla. In addition, (Guezoul et al., 2011) announced that the advent of cereal farming in the Sahara has increased the expansion of some bird species, including hybrid sparrows (Passer domesticus x P. hispaniolensis).

The latter and its analogues are known to cause serious damage to agricultural production (Dawson, 1970, El Kharrim etal., 1997, Ubaidullah, 2004, Khaleg Hizadeh, 2011, Kale etal., 2014, 2012, Mofokeng et al., 2016). In North Africa, several studies have reported the amount of the damage caused by sparrows (Passer $\mathrm{sp}$ ) on different agricultural crops ((Guezoul et al., 2005, 2006, 2010, El Kharrim et al., 1997, BORTOLI, 1969, and Bachkiroff, 1953). Simultaneously, the damage caused by sparrows on winter cereals in northern Algeria has been studied by (Metzmasher and Dubois, 1981, Bellatreche, 1983, Bendjoudi and Doumandji, 1998, Behidj-Benyounes and Doumandji, 2009, Ait Belkacem et al., 2012, and Behidj-Benyounes et al., 2014) So far, however, there has been little discussion about the assessment of bird damage on agricultural products in the Algerian Sahara. The current study aimed to present the first data on the damage the hybrid sparrows (Passer domesticus $x$ P. hispaniolensis) cause on cereals under Centre-pivot irrigation system in the North- eastern Algerian Sahara around the region of Ouargla.

\section{MATERIAL AND METHODS}

\section{Study area}

The present study was conducted in the region of Ouargla, part of the north-east Algerian Sahara (31 ${ }^{\circ} 56^{\prime} 40,05^{\prime N}, 5^{\circ} 19^{\prime} 4,63^{\prime}$ E). In Ouargla, the Rainfall is low and random across the year (Total annual rainfall was $16.5 \mathrm{~mm}$ in 2016 and $75.2 \mathrm{~mm}$ in 2017), also high thermal amplitudes are marked during the month of July (highest temperature was $49^{\circ} \mathrm{C}$ during 2017). Our study region is one of the most important in Algeria for date production. At the same time, in the traditional oasis agricultural system, cereals were grown in small plots planted under date palms (Idder et al., 2011). In the late 1980s, large cereal perimeters were installed in the Algerian Sahara as a consequence of the new agricultural strategies adopted by the Algerian government (Chaouch, 2018). During the 2016/2017 agricultural season, 1879 hectares of cereal fields were created in Ouargla (DSA, 2018). A total of eight different farms were selected across Ouargla for the assessment of hybrid sparrow damages in barley and wheat fields (Figure 1).

\section{Field work}

The study sites were visited 2 to 10 days before harvest, during May 2016 and 2017 to estimate damage caused by hybrid sparrows. All cereal parcels in the visited farms were examined. Each parcel was devised into quarters in which four sampling wooden squares $(50 \mathrm{~cm} \times 50 \mathrm{~cm})$ were established at random in peripheral and interior area. A total of 16 samples per parcel were collected (Figure 2). From each sample, ears density, the number of damaged ears, average of grain number per ear and the number of taken grains were recorded. 


\section{Plot yield and weight loss}

The average weight of the grains "Pm" was obtained from that of 100 healthy grains taken at random from each plot. Field yield $(Y)$ and weight loss $(W l)$ was calculated using the formula given by Behidj-Benyounes et al., 2014 which is presented as follows:

$$
\begin{aligned}
\mathrm{Y}=\mathrm{Nm} \times \mathrm{g} \times \mathrm{Pm} \times & 4 \times 10.000 \times 100.000 \text { quintals } / \text { ha } \\
& =\mathrm{Nm} \times \mathrm{g} \times \mathrm{Pm} \times 0.4 \text { quintals } / \mathrm{ha} \\
& \mathrm{Wl}=\mathrm{Dm} \times \mathrm{h} \times \mathrm{Pm} \times 0.4 \text { quintals } / \text { ha }
\end{aligned}
$$

Where, $\mathrm{Nm}$ is the mean number of ears in $0.25 \mathrm{~m} 2$; $\mathrm{g}$ is the mean of grain number in ears; $\mathrm{h}$ is the average number of taken grains per ear; and $\mathrm{Dm}$ is the average of damaged ears in $0.25 \mathrm{~m}^{2}$.

Damage rate $D r$ in each cereal plot is estimated as the ratio of weight loss to field yield multiplied by 100 .

$$
\operatorname{Dr}(\%)=\mathrm{W} 1 \times 100 / Y
$$

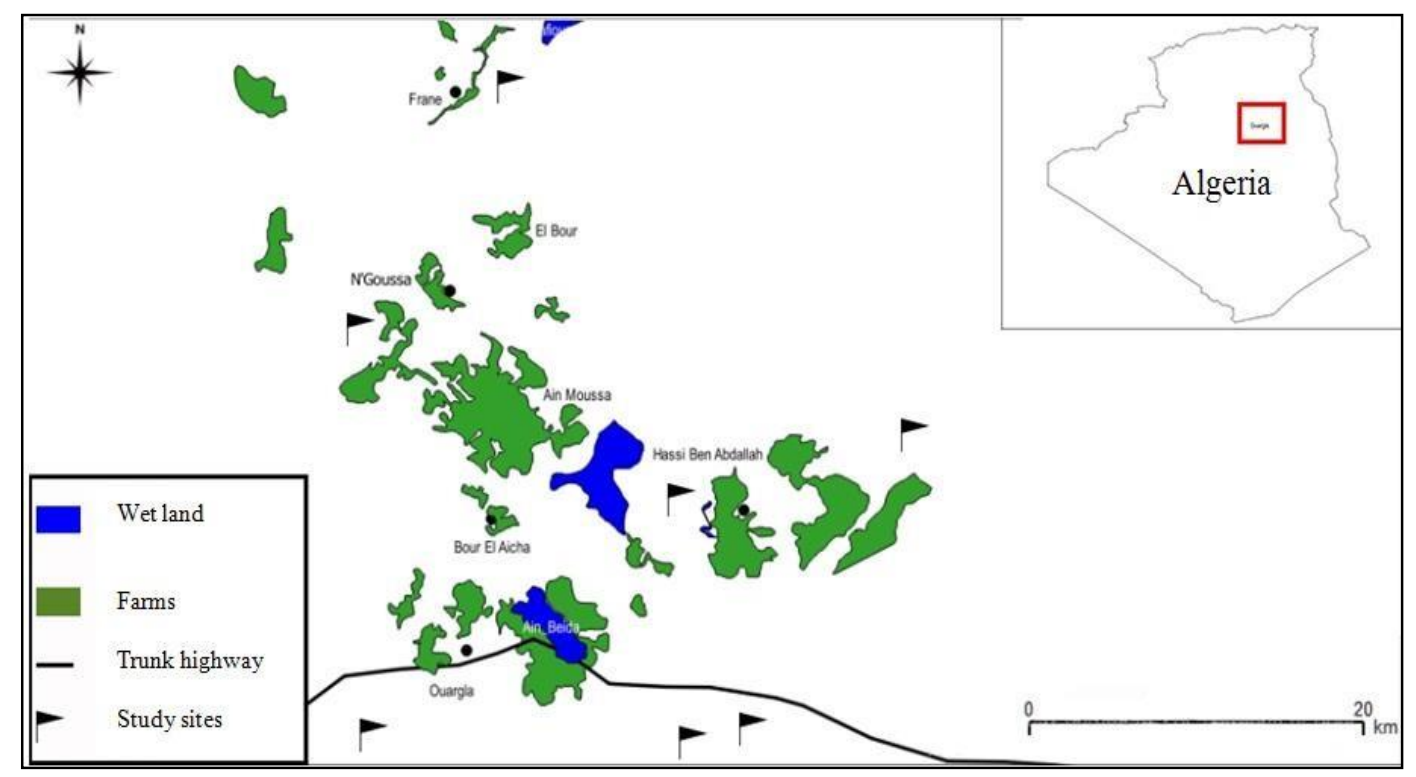

Figure 1. Study area and distribution of barley and wheat visited fields in 2016 and 2017 over the region of Ouargla. 

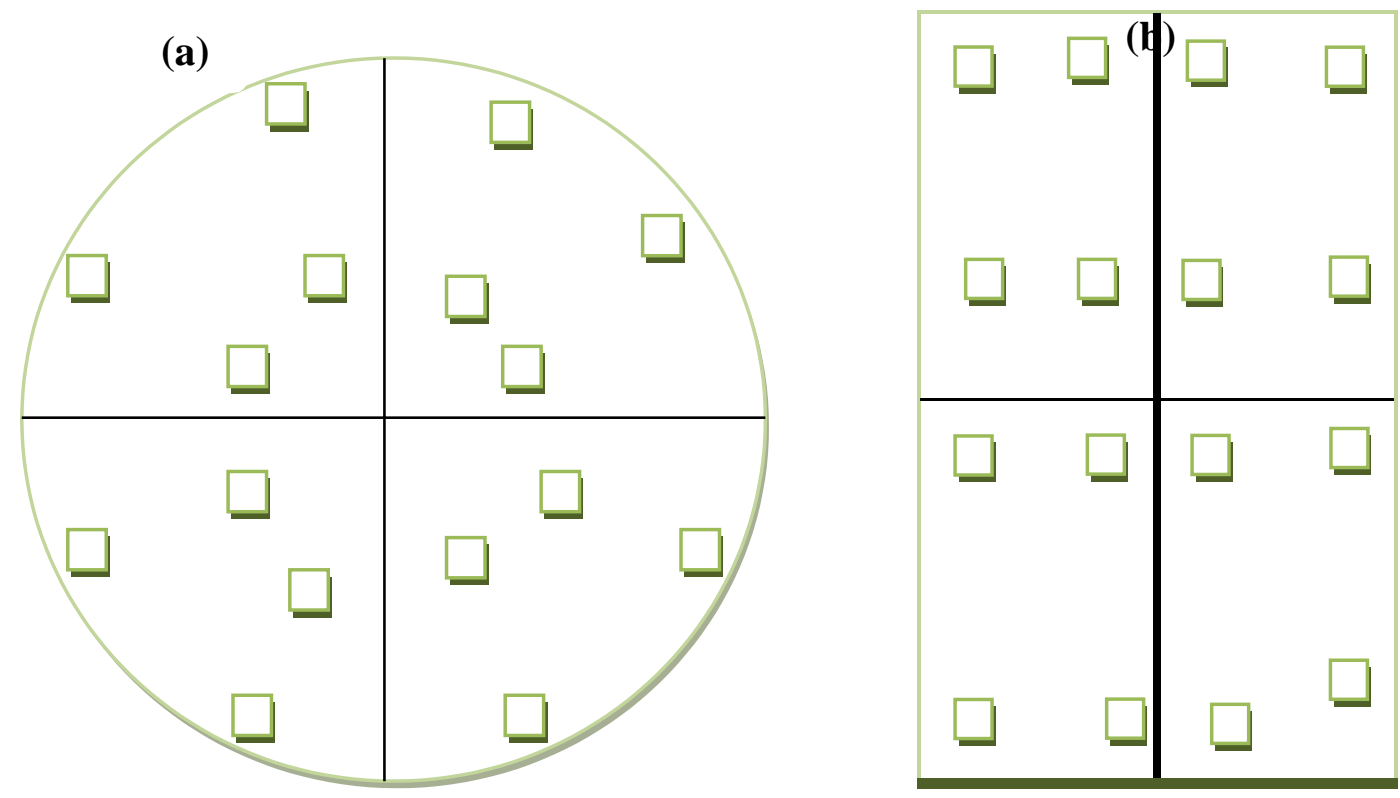

Figure 2. Distribution of sample squares across the study plot. (a) Sampling scheme in plots under center pivot irrigation system; (b) Sampling scheme in a rectangular plot.

\section{RESULTS}

In Ouargla, over all the inspected farms, a large difference in the rates of losses due to hybrid sparrows (Passer domesticus x P. hispaniolensis) was recorded in wheat and barley plots. In total, four of the sampled plots received more than $2 \%$ loss. The highest assessed amount of damage was $15.6 \%$ (10.8 qls/ha) while the lowest rate of damage was $0.28 \%$ ( 0.22 qls / ha) (Table 1$)$. For all the examined plots, the rate of damaged ears per sampled square was extremely heterogeneous and fluctuated on average between $16.7 \%( \pm 14.30)$ and $1.2 \%( \pm 2.87)$ (Table 1$)$. 
Table 1. Losses caused by Hybrid sparrows on cereal plots at six different sites in Ouargla.

\begin{tabular}{|c|c|c|c|c|c|c|c|c|c|}
\hline \multicolumn{4}{|c|}{} & \multicolumn{3}{c|}{ Average of damaged ears } & \multicolumn{3}{c|}{ Area with high damages } \\
\hline Farm & Area of the & $\begin{array}{c}\text { Theoretical } \\
\text { yield }\end{array}$ & Damaged & S.D. & Theoretical & Damage & size( $\left.\mathrm{m}^{2}\right)$ & Weight & Losses \\
\hline & $\begin{array}{c}\text { Examined } \\
\text { plot (ha) }\end{array}$ & (qls/ha) & Ears (\%) & & $\begin{array}{c}\text { losses } \\
\text { (qls/ha) }\end{array}$ & Rate (\%) & & $\begin{array}{c}\text { Loss } \\
\text { (qls) }\end{array}$ & Rate (\%) \\
\hline A1 & 1 & 29,00 & 11,98 & 13,97 & 1,52 & 5,24 & - & - & - \\
\hline A2 & 1 & 21,66 & 2,99 & 7,85 & 0,08 & 0,35 & - & - & - \\
\hline B & 20 & 77,88 & 2,40 & 6,85 & 0,22 & 0,28 & 710,00 & 0,34 & 7,73 \\
\hline C & 1 & 49,66 & 16,71 & 14,30 & 4,61 & 9,28 & 204,52 & 0,51 & 26,4 \\
\hline D & 30 & 48,62 & 1,15 & 2,87 & 0,06 & 0,13 & - & - & - \\
\hline E & 30 & 14,60 & 5,53 & 7,35 & 0,30 & 2,07 & - & - & - \\
\hline F1 & 1 & 67,75 & 21,30 & 34,30 & 10,57 & 15,60 & 198,00 & 0,65 & 28,27 \\
\hline F2 & 1 & 32,99 & 3,98 & 6,09 & 0,25 & 0,75 & - & - & - \\
\hline
\end{tabular}

$\mathrm{A} 1$ and $\mathrm{A} 2, \mathrm{~F} 1$ and $\mathrm{F} 2$ are the examined parcels in farm $\mathrm{A}$ and farm F respectively.

Furthermore, our results show that the percentage of attacked ears increases with the increase of ears number in sampling squares (Figure 3). Moreover, when considering all the sampled squares together, it turned out that the squares with grain losses had a high number of ears compared to sampled squares without damaged ears (Figure 4). Our results showed that, in all the visited cereal fields, seed losses in plot borders averaged $81.5 \%$ ( \pm 20.93$)$, while sparrow attacks on plot centers were less important and averaged $4.3 \%( \pm 4.47)$ of the recorded damage (Figure 5). In addition, in three of the inspected fields, we observed areas in which the rate of damage was significantly different from that of the whole plot $(\mathrm{t}=3.36, \mathrm{p}=0.008)$. These areas are spread over an area of less than 1 ha and are located at the boundaries of the cereal plots near date palm blocks or (Casuarina sp.) trees (Table 1). In addition, we found that the rate of damage decreased with increasing distance from the nearest perches, namely, date palms and trees (Figure 6). An examination of the whole farm revealed that only one of the plots of grain is severely damaged, if the inspected farm contains several cereal parcels although they are grown under the same conditions. 


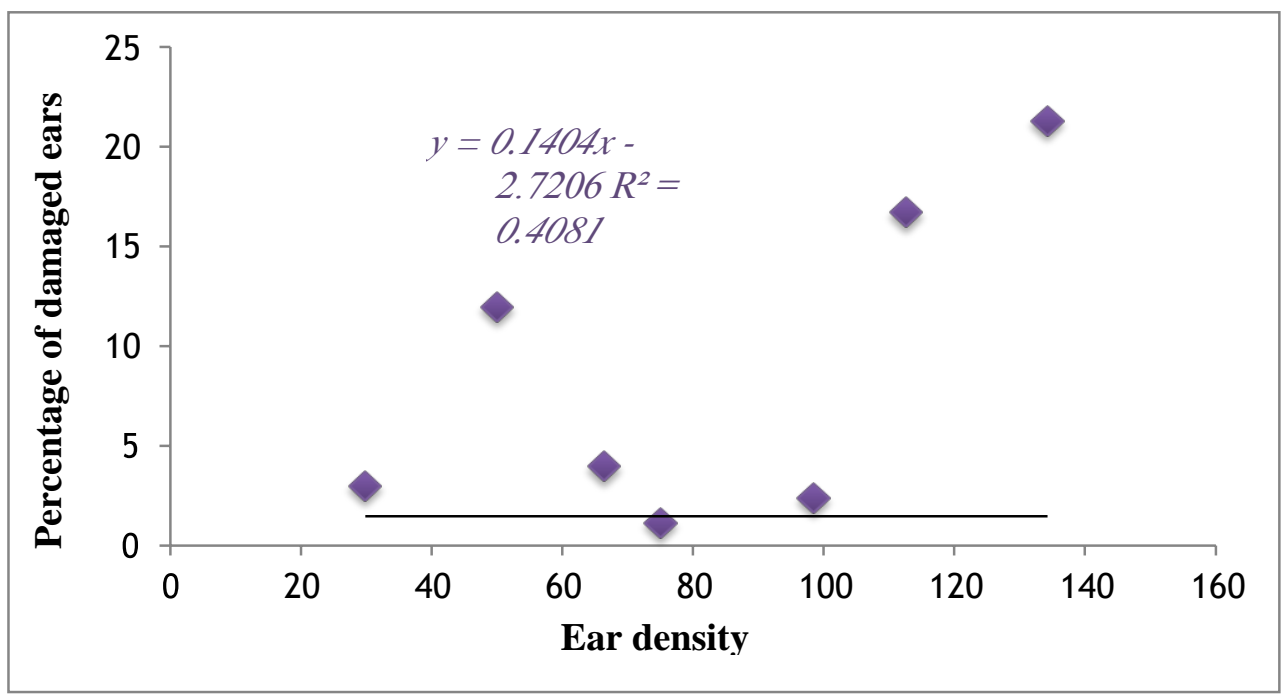

Figure 3. Percentage of damaged ears per field (indicated as the average percentage of damaged ears per sampled square) in relation to the average density of ears per field.

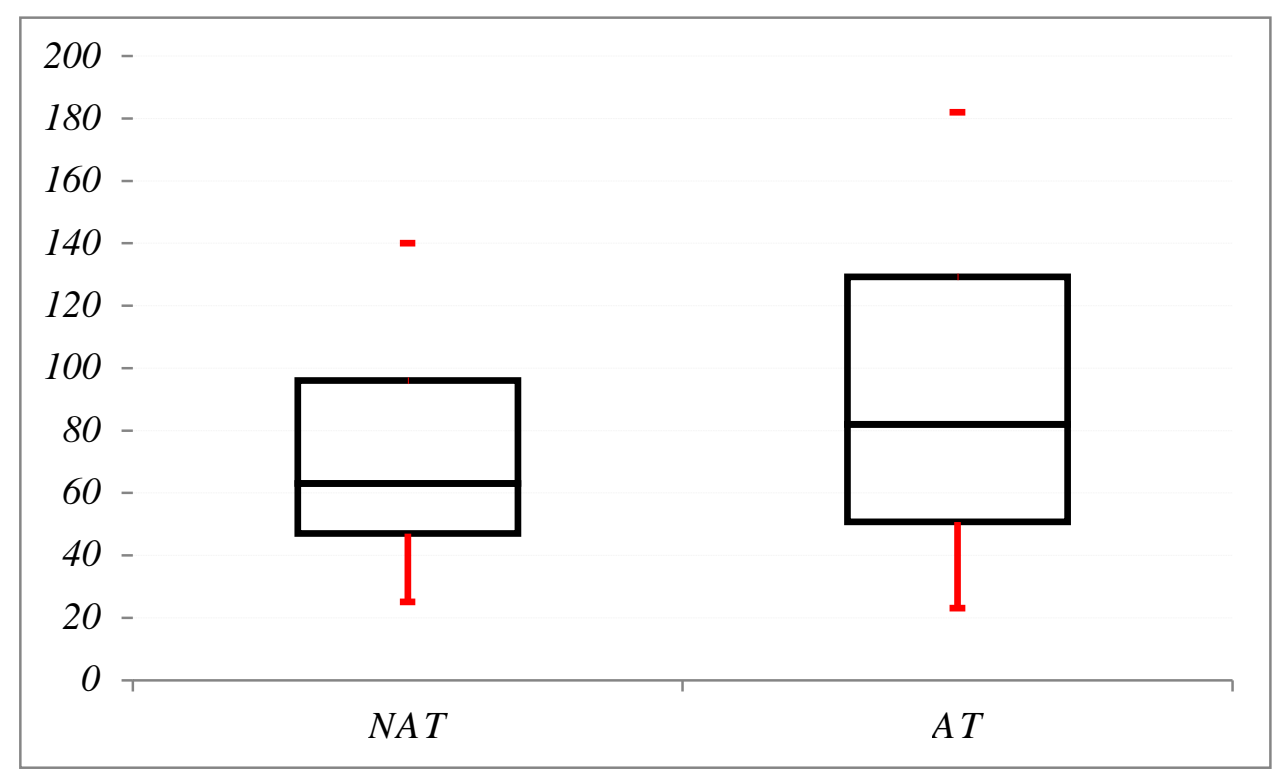

Figure 4. Number of ears in sampled squares in all farms together presented in box plots (median, upper and lower quartile, maximum, minimum, and outliers). AT=sampled squares with hybrid sparrow damages, NAT= sampled squares without hybrid sparrow damages. 


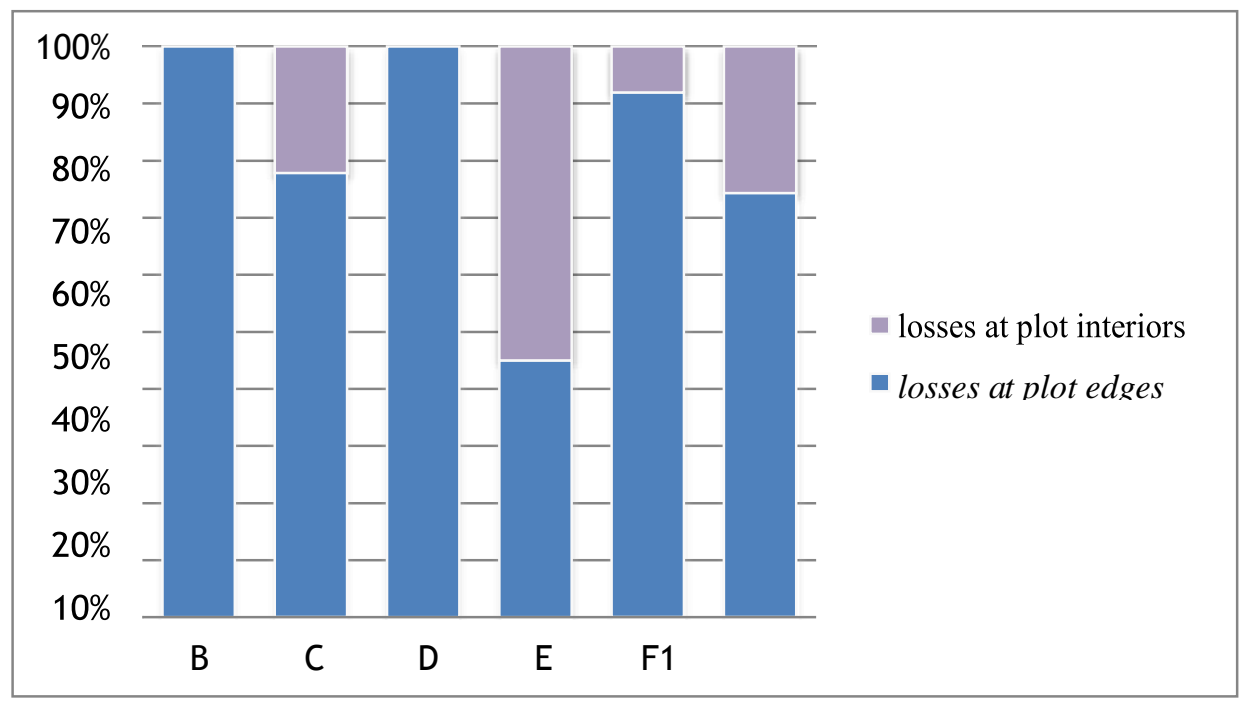

Figure 5. Losses due to hybrid sparrows at the edges and interior of cereal plots.

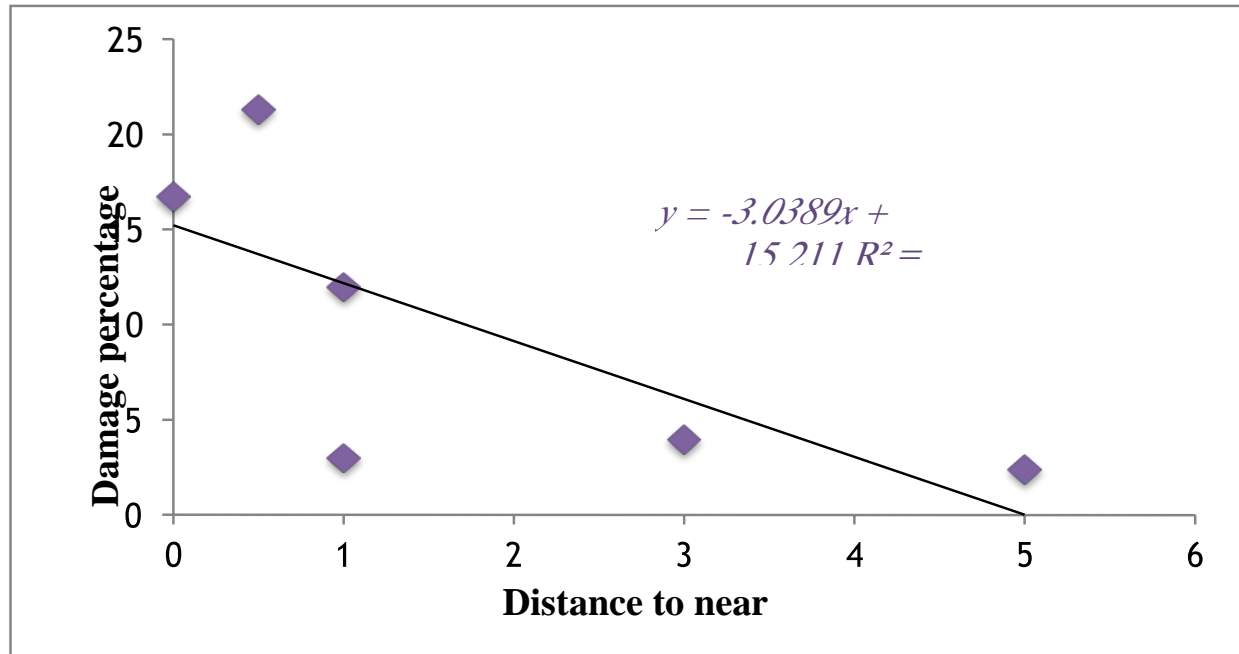

Figure 6. Percentage of damage per field (indicated as average percentage of damage per sampled field) in relation to distance from nearest perch.

\section{DISCUSSION}

According to several bird population studies in different regions across the Algerian Sahara, and particularly in Ouargla, the hybrid sparrow is present in high densities compared to other avian species (Guezoul et al., 2011, Ababsa et al., 2013). Prior reports in date production regions have shown that, in Ouargla, a significant economic damage is caused to dates of Phoenix Dactylifera due to hybrid sparrow attacks (Guezoul et al., 2010 and BENRAS et al., 2017). Through the study sites and during the execution of the current work, groups of hybrid sparrows composed of about 100 individuals were seen visiting cereal plots to find their food, perch on pivot lateral, or 
even nesting in engine-generator buildings constructed at the center of the plots.

The information collected in 2016 and 2017 on the damage caused by hybrid sparrows on wheat and barley shows that in Ouargla, in all the visited farms, these birds have a variable economic impact on cereal plots (Table 1). This difference in percentage of attack in the visited sites is essentially due to the difference in farms organization and planning. According to (Christopher et al., 2002), the attractiveness of farms to pest birds depends strongly on their type of organization. It is interesting to note that no sparrow was recorded in two of the visited sites, these farms were newly installed in the desert (1st year of installation) without any other crop in association. Therefore, the use of polyculture in arid and semi-arid regions should be reduced (Guezoul, 2011). Our results are comparable to previous results of studies on sparrow damage in other parts of Algeria; the first ever study carried out on the losses caused by Spanish sparrows on cereals was conducted by (Metzmasher and Dubois, 1981) in Oran; According to these authors, 15.2\% and $5.0 \%$ of grain losses due to sparrows occur in barley and wheat plots respectively. In Mitidja, during a study conducted from 2000 to 2007, (Behidj-Benyounes et al., 2014) estimated 8.5 - 39.8\% of damage caused by hybrid sparrows on wheat. While (MADAGH, 2013) reported in the same locality, that the maximum of grain loss in different wheat varieties was 3.2 qls / ha.

The present results show that the highest rate of attacked ears was recorded at the borders of the inspected cereal plots. This finding is consistent with that of (Borad, 2001, Christopher et al., 2002, Guezoul, 2010 and Schäckermann et al., 2014) who found that most pest birds occasion more damage to margins of the plots than to their interior parts, mainly because of the presence of trees or buildings on the periphery. In our study area, we noted near the studied cereal plots, the presence of palm trees and tall trees of Casuarina. Our results reveal a positive relationship between the proximity of cereal plots to perches (mainly trees) and the overall percentage of grain loss in the plot. These results are comparable to those obtained by (Schäckermann et al., 2014) who reported that sunflower seed losses caused by the Ring-necked Parakeet (Psittacula krameri Scopoli) decreased with increasing distance of sunflower parcels to trees less than $50 \mathrm{~m}$. According to (Behidj-Benyounes and Doumandji, 2009), barley plots located near abundant vegetation and water sources are the most visited by hybrid sparrow.

In three of the visited farms, we noticed plots with heavily damaged areas around the edges. (Kale et al., 2014) and (Dawson, 1970) point out that sparrows tend to concentrate on certain areas in cereal parcels, and that they continue feeding until the food in this area is exhausted before moving to a new area. Our results also reveal a positive relationship between the density of ears per sampled square and the number of damaged ears. These results strongly agree with the conclusions of (Metzmasher and Dubois, 1981) who noted that, for barley, the damage caused by the Spanish sparrow was significantly related to the yield index and perch abundance. Contrary to our results, evaluations by (Abdel-Gawad et al., 2010) have shown that house sparrows prefer feeding on plots of sown pea with large spacing between plants than on those with reduced spacing. 


\section{CONCLUSION}

In Ouargla, assessing the damage of hybrid sparrows on cereals has allowed us to figure out that the amount of losses varies from one farm to another. This paper has argued that this damage is influenced by the organization and disposition of each farm. Sparrow damage was found to be strongly influenced by the presence of all kinds of perches around the cereal plots. In the Sahara, isolated farms with a purely cereal specialty are the most protected from sparrow attacks. An in-depth study on the assessment of sparrow damage on cereals in the Algerian Sahara from the sowing period to the harvest of the crop seems interesting.

\section{REFERENCES}

Ababsa, L. Sekour, M. Souttou, K. Guezoul, O. et Doumandji, S. 2013. Quelques aspects sur l'avifaune dans deux palmeraies du sahara septentrional (Algérie). Algerian Journal of Arid Environment 3(1): 59-67.

Abdel-Gawad, H. Metwally, M. Mahmoud, A. et Omar, M. A. 2010. Effect of Broad Bean Sowing Distances on Damage Caused by House Sparrow, Passer domesticus Niloticus (L.). Assiut Jornal of Agricultural Sciences, (The 4th Conference of Young Scientists Fac. of Agric. Assiut Univ. 41: 216-22.

Ait Belkacem, A. Sekour, M. and Doumandji S. 2012. Effectiveness of mesh netting and nest' destruction in protection of crops against attack by Spanish sparrow Passer hispaniolensis. African Journal of Agricultural Reseearch, 7(32): 4575-4580.

Behidj-Benyounes, N. et Doumandji, S. 2009. Les attaques journalières de trois parcelles d'orge Hordeum vulgaris L. par le Moineau hybride Passer domesticus x $P$. hispaniolensis dans la Mitidja orientale. Lebanese Science Journal, 10(1): 55 -62.

Behidj-Benyounes, N. Bissaad, F. Behidj, K. Chebouti, N. et Doumandji, S. 2014. Différences inter parcellaires des dégâts dus aux individus de passer domesticus $x$ p. hispaniolensis sur orge dans un milieu agricole près de boudouaou (algérie). Lebanese Science Journal, 15(1): 73-83.

Benras, H. Benghedier, A. Guezoul, O. 2017. Dégâts dus aux moineaux hybrides sur les dattes de la variété Ghars dans une plantation phœnicicole à Ouargla. Proceeding des journées d'études sur la biodiversité animale, dégâts et lutte, 24 et 25 mai 2017. Ecole Nationale Supérieur Agronomique. Alger, Algérie.

Borad, C. Mukherjee, A. Parasharya, B. 2001. Damage potential of Indian sarus crane in paddy crop agroecosystem in Kheda district Gujarat, India. Agriculture, Ecosystems \& Environment, 86(2): 211-215.

Chaouch S. 2018. Dynamique de l'espace agricole et mutations dans le Sahara algérien, cas de la région de Ouargla (le pays d'oued m'ya). Revue des BioRessources, 8(1): 111-123.

Christopher M. S. Ralph D. M. 2002. Birds and Wine Grapes: Foraging Activity Causes Small-Scale Damage Patterns in Single Vineyards. Journal of Applied Ecology, 39(3): 511-23.

Dawson, D. G. 1970. Estimation of grain loss due to sparrows (Passer domesticus) in New Zealand. New Zealand Journal of Agricultural Research, 13(3): 681-688.

Djili, K. Daoud, Y. Gaouar, A. Beldjoudi, Z. 2003. La salinisation secondaire des sols au 
Sahara. Conséquences sur la durabilité de 1'agriculture dans les nouveaux périmètres de mise en valeur. Science et changements planétaires/Sécheresse, 4(4): 241-246.

DSA. 2018. Direction des services agricoles à Ouargla (Algérie).

El kharrim, K. sehhar, E. belghyti, D. Ahami, A. et Aguesse, P. 1997. Évaluation des dégâts sur les cultures céréalières à travers l'étude du régime alimentaire du moineau domestique Passer domesticus L. dans la plaine du Gharb (Maroc). Actes Inst. Agron. Veto (Maroc), 17(1): 61-66.

Guezoul, O. Chenchouni, H. et Doumandji. S. D. 2011. Breeding Biology in Hybrid Sparrow (Passer domesticus x P. hispaniolensis) in Northern Algerian Sahara: Case Study of Biskra Date Palm-Grove. Journal of Advanced Laboratory Research in Biology, 2(1): 12-17. E-ISSN0976-7614.

Guezoul, O. Doumandji, S. Baziz, B. Souttou, K. et Sekour, M. 2005. Estimation des dégâts dus aux moineaux hybrides Passer domesticus x P. hispaniolensis sur les dattes de Phoenix dactylifera à Filiache (Biskra). Proceeding de la 9ème Journée d'Ornithologie, 7 mars 2005, laboratoire d'ornithologie appliquée, département de zoologie agricole et forestière, institut nationale d'agronomie, El Harrach, p.13.

Guezoul, O. Doumandji, S. Baziz, B. Souttou, K. Sekour, M. Ould Rabah, S. et Ait Belkacem, A. 2006. Le Moineau hybride un ravageur méconnu- estimation de ses dégâts sur les dattes dans une palmeraie à Biskra, en Algérie. Phytoma-La défense des végétaux, 595: 13-15.

Guezoul, O. M. Sekour, K. Souttou, et S. Doumandji. 2010. Estimation des dégâts dus au moineau hybride passer domesticus x p. Hispaniolensis sur les dattes (phonix dactylifera) dans deux palmeraies a ouargla. Acta Horticulturae, 994 :341-46.

Idder, M. A. Bouammar, B. Idder-ighili, H. 2011. La palmeraie du Ksar d'Ouargla; entre dégradation et réhabilitation. Annales des Sciences et Technologie, 3(1): 12-20.

Kale, M. A. Dudhe, N. Kasambe, R. \& Bhattacharya, P. 2014. Crop Depredation by Birds in Deccan Plateau, India. International Journal of Biodiversity, ID: 947683, 1-8.

Kale, M., Balfors, B., Mörtberg, U., Bhattacharya, P., \& Chakane, S. 2011. Damage to the Agricultural Yield due to Birds, Present Repelling Techniques and its Impacts: An Insight from the Indian Perspective. International Journal of Applied Agricultural Research, 6 (3): 223.

Khaleghizadeh, A. 2011. Effect of morphological traits of plant, head and seed of sunflower hybrids on house sparrow damage rate. Crop Protection, 30(3): 360367.

Madagh, M.A. 2013. Bioévaluation des dégâts dus aux oiseaux (moineaux hybrides) dans un agroécosystème aux environs d'Alger. Proceeding du 4th International Congress of the Populations \& Animal Communities "Dynamics \& Biodiversity of the terrestrial \& aquatic cosystems""CIPCA4"TAGHIT (Bechar)-Algeria.

Metzmacher, M. et Dubois, D. 1981. Estimation des dégâts causés par les oiseaux aux céréales en Algérie. Revue d'écologie (Terre et Vie), 35(4): 581-595.

Mofokeng, M. A. \& Shargie, N. G. 2016. Damage and control strategies in grain sorghum production. International journal of agricultural and environmental research, 2 : 264-269.

Ould EL Hadj, M. D. 2002. Les nouvelles formes de mise en valeur dans le Sahara algérien et le problème acridien. Science et changements planétaires / Sécheresse, 
13(1): 37-42.

Schäckermann, J. Weiss, N. Wehrden, H. V. and Klein A. M. 2014. High trees increase sunflower seed predation by birds in an agricultural landscape of Israel. Front. Ecol. Evol. 2: 35.

Ubaidullah, M. 2004. Losses Due to House Sparrow to Wheat Crop in Central Punjab. International Journal of Agriculture and Biology, 6(3): 541-543. 